\section{PITA AMOR, UN MITO MEXICANO}

PITA AMOR, A MEXICAN MYTH

La escritora mexicana Guadalupe Amor que se The Mexican writer Guadalupe Amor became convirtió en un mito mexicano de los años 50's a Mexican myth during the 50's and 70's of y 70's del siglo XX. Se inspiró en los místicos the XX century. She inspires herself with the castellanos para escribir su poesía. Rompió Spanish mystical in order to writer her poetry. con las reglas de conducta establecidas en She broke all the behavior rules from her age, su época, hizo cuentos basados en la idea de made short histories with the idea that her que los personajes que ahí aparecen son una characters were handled for the destiny and galería de títeres manejados por la mano del told her own autobiographic roots in her only destino y contó sus orígenes autobiográficos novel. Her tragic end can be dedued from en la única novela que escribió Su final trágico the history she was pulling and gets hed from en la unica novela que escribio. Su final tragico the history she was pulling and gets her final puede deducirse de una conducta que venía result with her son's death.

arrastrando y que culminó con la muerte de su hijo.

\section{KeY WORD:}

\section{Palabras claves:}

Language, Spanish, biography, roots.

Lengua, español, biografía, orígenes.
Cuándo Guadalupe Dueñas le preguntó cómo quería que la describiera para hacer una semblanza sobre ella, Pita Amor le contestó con su irritante confianza característica: "Preferiría que estuvieras convencida de mis poderes mágicos, que poseo una antena de prodigio y admiraras el torrente de mi ciencia. Descubrirías que tengo un pacto diabólico para concederme la sabiduría. Por eso en lo alto del Parnaso los dioses deletrean mi nombre" (Dueñas, 1977: 35-36). Con ésta y respuestas por el estilo en que parecía una musa escapada del Olimpo logró cimentar un mito y construir un marco lujoso a su persona. Los espejos reflejaban su figura bajita, bien formada, redonda, ojos amelcochados, una anchoa sobre la frente y boca en forma de corazón como las de las muñecas kiupi populares en su niñez. Sabía estar en donde causara comentarios. Blanca marmórea, detestaba la piel morena e insultaba a quien se le ponía delante llamándolo indio. Trataba al servicio insolentemente, lo mismo en la casa de su infancia que a quienes lidiaron las horas de su decrepitud, primero en diferentes hoteles ${ }^{\underline{1}} \mathrm{y}$ luego en la azotea del edificio Vizcaya donde se refugió gracias a la benevolencia de un amigo y desde donde bajaba escaleras de caracol que bendecía a cada tramo porque eran muestra de que aún podía bajarlas, o en un garaje de la primera planta. Dormía enroscada como perrillo asustado sobre una cama de hospital. Al frente había sillones que tenían resortes a punto de reventar y olían a orines. No había nada más. Algunas baratijas, una televisión constantemente prendida y una mujer cuidándola temerosa. Porque con ella no existían medias tintas, como dijo su incondicional Jaime Chávez, uno de los pocos que la soportaron hasta el final, o se la adoraba o se la aborrecía. Pero el entorno quedaba en Bucareli, cerca de la calle donde había crecido.

Mientras esto no pasaba, Pita vivió en un lujoso departamento de la Colonia Juárez en la calle Duero número 52, esquina Pánuco. Elegía para vestirse modelos firmados por los modistas de moda como Henri de Chatillón, organizaba fiestas en su casa o asistía a la de los intelectuales donde arriba de las mesas se desnudaba en las oportunidades propicias. Demostraba que su hermosura era cierta y que no temía revelarla. Asistía a corridas de toros con sacos sastres orlados de zorros. Sentada en barrera de primera o segunda fila festejaba la fiesta y, decían, que se llevaba al triunfador de la tarde junto con la oreja cortada que debió dejar en su mesilla de noche. Era una de las celebridades asistentes entre las que se contaban Agustín Lara y María Félix. Pertenecía al tipo de artistas provocadores que unos admiran y otros ponen en duda.

Publicaba en diferentes diarios, revistas y suplementos, América, Hoy, El Nacional, México en la cultura. Tenía un programa en televisión de la que fue pionera, pues antes que ella sólo apareció Amalia Hernández, “Nocturnal” de media hora cada tercer día a las diez de la noche. Lo trasmitían en vivo. Al inicio recitaba una de sus décimas y

1 El Hotel Del Bosque, los Departamentos Washington, incluso sobre este último hay un dibujo que Pedro Friedeberg hizo con plumón describiendo todos los objetos y muebles que lo componían. También le ilustró La jungla, una de sus últimas publicaciones. 
lo cerraba con otra. El resto del tiempo recordaba poemas suyos o de sus maestros. Llenaba el estudio con voz poderosa, imitable y paradójicamente inconfundible. Llegaba escoltada por Dolores Puche, Sergio Astorga y, a veces, Cordelia Urueta, alhajada y metida en largos trajes de terciopelo negro que descubrían sus hombros magníficos. El espectáculo duró poco más de año y medio y fue cancelado por un curioso incidente, uno de los tirantes se desprendió mostrando al aire un seno. Pero al poco tiempo siguió apareciendo convocada por Emmanuel Carballo en el primer programa del tipo patrocinado por el Fondo de Cultura Económica, "Invitación a la Cultura". Repartía en las redacciones de los periódicos retratos suyos como si fueran volantes y se le veía en todas partes. Daba recitales en el Auditorio de la Facultad de Medicina en Ciudad Universitaria. Esa publicidad, a la que era proclive de manera nata y quizás impulsada gracias a los ejemplos de Diego Rivera y Frida Kahlo que la invitaban con grandes muestras de júbilo a la Casa Azul de Coyoacán, le valió un público fiel y una reputación dudosa compartida por otras mujeres como Nahui Ollín, Lupe Marín, María Asúnsulo, Tina Modotti, Machila Armida, que habían abierto caminos y roto tabúes hacia la libertad sexual. Pita era dueña de su cuerpo y enfrentaba las consecuencias en un México que intentaba ser cosmopolita; pero condenaba sin miramientos a quienes rompían las llamadas buenas costumbres.

Los creadores plásticos contribuyeron a celebrarla. Enrique Asúnsulo le hizo un retrato premonitorio, un óleo sobre tela (1949) con flores de pensamientos en la cabeza y sobre el escote, frente a unos escalones y un arco abierto hacia la nada. Juan Soriano la pintó con una lira sin notas, Manuel Rodríguez Lozano olvidó la ironía y consiguió una obra excepcional, Cordelia Urueta la captó como un ser escindido y cargado de culpas, Gustavo Montoya celebró su fuerza, Raúl Anguiano eligió la pose más atrevida sentada en una silla con las piernas separadas mostrando el sexo y los brazos atrás de la cabeza para darle a los pechos todo su esplendor. Diego Rivera la tomó como modelo tres veces: para un óleo sobre tela (1949) con los hombros descubiertos en un vestido primaveral, el cabello alborotado y la mirada puesta en el abismo de la enajenación; a lápiz, con un pañuelo en la cabeza, y de cuerpo entero parada completamente desnuda sobre un páramo apuntando con una varita su nombre y amenazada por un nubarrón que evocaba la consabida frase, "Yo soy polvo". Lo terminó el 29 de julio de 1949. Cuando se inauguró la muestra, el Presidente de la República Miguel Alemán dejó que colorearan leves rubores sus mejillas de hombre mundano, a pesar de haberse propuesto internacionalizar nuestro país impulsando obras como Ciudad Universitaria (principio de la modernidad en Latinoamérica), viaductos, playas de moda y multifamiliare enormes para su época. El polvo no sólo aludía a nuestra condición mortal sino a uno de los libros de Pita. Sobre este cuadro, Sergio Fernández escribió:
El retrato que le pintó Diego Rivera -entre bueno y repugnante- la dotaba de una piel carnosa, de plátano mondado, de modo que al enseñárnoslo precisamente aquella tarde, lo sacó de su recámara con miradas de cierta ambigüedad, como sin saber a qué atenerse con él. Fue durante una velada en su departamento de Duero. Salió de su recámara -digo- envuelta en un abrigo de mink, o algo parecido. Entonces para hacer una comparación entre ella y la "otra", se quitó la prenda -que cayó suavemente al pisoquedándose desnuda. Fueron como dos Evas de algún pintor flamenco, que molestan y encantan a la realidad con punzantes líneas ironizadas; dos Evas, convertidas en mujer que tenían un cuerpo irregular, de imagen aparentemente inocente, ambas sorprendidas cuando miraban al mundo y se miraban a sí mismas, sin saber por qué habían nacido en el mismo vientre del mito (Fernández, 2005: 19-20).

Los fotógrafos pusieron su grano de arena con instantáneas callejeras o captándola en estudios de moda como el Hollywood, o el de Tufek Yazbek o bajo las lentes de Berenice Kolko, Kati Horna, Ricardo Salazar, Daisy Asher. Quizás aprendió poses desde que a los pocos meses de nacida la retrataron desnuda junto a las macetas, lo cual le costó una bronconeumonía que la llevó al borde de la muerte. “Mi infantil desnudez agradó sobremanera a toda mi familia. Más por la tarde de aquel día comencé a toser persistentemente; y hacia las nueve de la noche, encendida en fiebre, lloraba en los brazos de mi madre que, desesperada, llamó a su médico de cabecera" (Amor, 1959: 169). Los escritores incrementaron la imagen de esta mujer que por haber sido desafiante, controvertida, ocurrente, por haber saltado barreras dio lugar a cuentos, biografías, novelas, obras de teatro, y en su momento se convirtió en la escritora mexicana más popular con un público que la reconocía en cualquier parte, como dije antes. Había incursionado en el cine. Participó en “La guerra de los pasteles", “Tentación”, dirigida por Fernando Soler y escrita por Mauricio Magdaleno, en "Los cadetes de la Naval", "El que murió de amor". Pisó el teatro con "La dama del alba", donde le quitaron el papel, "En qué piensas", “El diablo volvió al infierno", de Miguel N. Lira, cuyas representaciones no terminó porque otra vez le quitaron el papel a pesar de haberlo representado con mucho éxito, y "Casa de muñecas". Se felicitó por adelantado, organizando un cóctel en la galería de sus hermanas, por actuar bajo la dirección de Luz Alva que le brindaba la oportunidad del estrellato en el Teatro Mexicano de Arte. Interpretó allí una Nora que nada tenía que ver con la de Ibsen. Salvador Novo le echó la culpa del fracaso a una pieza en su opinión envejecida (Novo, 1965: 506). Se cuenta que Pita usaba un alfiler de sombrero para enterrárselo a su contraparte femenina y apoderarse de la escena. Cierta o falsa la treta no duró mucho. Comprendió que su reino estaba en las letras y en ambientes literarios proclives a cultivar su celebridad.

Guadalupe Teresa Amor nació el 30 de mayo de 1917, en una casa de 600 metros cuadrados y cuarenta habitaciones construida por el arquitecto inglés Charles Johnson, 
el número 66 de la calle de Abraham González, entre General Prim y Lucerna. Tenía ocho recámaras, varios baños, hall, pasillo, juguetero, costurero, alacena, otro hall en la planta baja con un tragaluz florentino, comedor, galería, biblioteca, antecocina cocina, un lugar para el planchado, una especie de bodega, tres sótanos, cava, túneles, cocheras para troncos de caballos, jardín arisco, siete almenas en la azotea, siete truenos plantados en la acera y quién sabe cuántas cosas más. Pita fue el último parto de Carolina Schmidlein García Teruel, hija de un médico alemán llegado a México hacia 1864 en las tropas que acompañaron a Maximiliano, y Emmanuel Amor Suberville dueño de una enorme hacienda en Morelos, expropiada por las fuerzas zapatistas durante la Reforma Agraria, y de dos herencias recibidas gracias a dos matrimonios, por una viudez temprana. Procrearon seis muchachas y un hombre. Ella tenía una belleza que ninguna de sus hijas igualó, alrededor de los diecinueve años fue novicia pero seguramente cambió de opinión y se dedicó a concebir como verdadera católica. Entre Manuela, Mimí, y Pita mediaban catorce años de edad. Él, embargado por una enorme devoción y la tristeza de fracasos financieros, poco a poco fue refugiándose en su biblioteca entregado a la lectura de la Suma Teológica, interesado en sostener conversaciones sobre altos designios divinos con sacerdotes de su amistad, atento a reuniones organizadas por los Caballeros de Colón, escribiendo poemas que no se conocieron sino hasta después de su muerte.

Aunque al varón, José María, rubio y muy simpático, lo mandaron a Stonyhurst, Inglaterra, porque un tío le pagó la colegiatura y era tradición que allí estudiaran los jóvenes de buena familia para que regresaran presumiendo acento inglés y buenos modales. Pita, acompañada por Maggie, tomó clases con Mimí en el juguetero. Improvisaron el Colegio Libélula (sin acento) que abría su puerta después del desayuno sobre una mesa redonda muy grande generalmente cubierta por carpeta bordada en punto de cruz. El primer plato eran lecciones de catecismo, los siete pecados capitales y la sombra luminosa de las siete virtudes teologales, los diez mandamientos de la Santa Iglesia. Pita aprendió el Padrenuestro y hasta el Yo Pecador. Repasaba las Bienaventuranzas, Historia Sagrada. Se conmovió con la imagen de Moisés encontrado primero entre los juncos del Nilo que después de haber conducido a su pueblo al través del desierto, un castigo divino le impidió entrar y tuvo que contentarse contemplando la expedición desde lo alto de un monte. Le enseñaban lecciones de francés, "avec a: ra, na, ma; avec e, re, ne, me"; algo de español, algo de matemáticas. Dibujaba líneas, triángulos, estrellas, peras y racimos de uvas que convertía en figuras estrafalarias y siguió trazando su vida entera para regalarlos a quienes se los solicitaban. En ese cuartito había un mapamundi descolorido y un ropero lleno de libros desencuadernados por las manos de todos los mayores; pero encontró allí el cofre del tesoro. Leía cuentos fascinantes, "Piel de Asno" con sus trajes color tiempo, "Caperucita Roja" asustada en el bosque a punto de ser comida por el lobo, la Princesa Leonor tejiendo túnicas hechizadas para desencantar a los cisnes, "Blanca Nieves" con su manzana atorada en la garganta y su cutis impecable que despertaba envidia y amor en cuantos la contemplaban y, claro, historias más extensas como La cabaña del tío Tom. Y en las altas horas de la noche temida y asesina, víctima de insomnios que siempre la atormentaron, salía de su propio cuarto para llegar a la biblioteca en cuyo estante bajo había gruesos tomos de la Enciclopedia Británica que hojeaba sin parar.

A los nueve años ingresó al Motolinía. Inició su peregrinar por varias instituciones. Sufría lo indecible porque en el patio formaban a todas las alumnas siguiendo orden de estatura y siempre encabezaba la fila aunque las dos niñas precedentes fueran año y medio menores que ella. Allí empezó a descubrir ciertas inclinaciones suyas. “...esta señorita Pinedo, flaca y con un bucle forzadísimo adherido en la frente, me inspiraba una debilidad curiosa. Cuando me castigaba diciéndome que permaneciera a su lado y escribiera cien veces: No lo volveré hacer nunca, temblaba yo de emoción, y sólo temía que ella, demasiado bondadosa, me levantara el castigo" (Amor, 1951: 41). Se avergonzaba porque nunca llevaba los útiles completos y los que cargaba consigo, en vez de estar forrados de hule negro, traían un papel lustroso que se rompía pronto aunque los cuidara, y ansiaba los zapatos relucientes de sus compañeras. En el Colegio Francés al que ingresó luego, cerca de los once años, sufría porque sus compañeras tenían dinero y las monjas les preparaban mantelitos o fundas para que bordaran flores y aves dibujadas de antemano, mientras ella se conformaba con un punto atrás que seguía los cariñosos inventos de su madre sobre pedazos de telas usadas. Una compañera murió de tifoidea y tuvo accesos de pánico temiendo contagiarse de lo mismo. Le horrorizaba la muerte, las noches se le convertían en tortura con una oscuridad sin resquicios y, curiosamente, al descubrir cualquier ventana iluminada creía que velaban cadáveres. Se atormentaba pensando que dentro de su propio cuerpo había un esqueleto y le pedía a Dios que hiciera una excepción con ella y la dejara asistir al fin del mundo conservando sus facciones y hasta su peinado aunque como a la Pitonisa de Cumas tuvieran que guardarla en un frasquito.

Las Damas del Sagrado Corazón fue la peor de sus escuelas. Le dio un ataque de histeria sólo al ver sus monótonos muros de ladrillo rojo y contemplar el desfile de monjas sombrías. Y cuando a las cinco y media de la mañana la despertaba una brutal campana acompañada por una voz, “Corazón Sagrado de Jesús, Corazón Sagrado de María. Rueguen por nosotros", se sentía condenada al patíbulo y a punto de cumplir sentencia. No le gustaba la galería del dormitorio con camitas puestas de lado y lado, ni que la obligaran a bañarse metida en una especie de camisa protectora de la pureza. Detestaba su austero uniforme confeccionado con una lana que había pertenecido a sus hermanas mayores, arreglado a su medida ostentando cicatrices y pespuntes en los tablones y jamás usaba ropa interior lo cual causó un pequeño alboroto. Su escena 
culminante ocurrió en el gran salón con todas las internas reunidas al momento de rezar oraciones comunes. Se negó a hincarse y cuando una maestra intentó empujarla de un hombro, ciega de rabia le dio un golpe en la cara que le lanzó la dentadura postiza y los lentes hacia el techo. Y a pesar de que la Madre Superiora había sido amiga de su mamá, las religiosas se dieron por vencidas en su intento de educar semejante engendrito.

Su padre murió de uremia a los setenta y seis años una mañana de julio de 1932. Para proteger sus nervios quebradizos enviaron a Guadalupe con amigos cercanos durante el novenario. Cuando volvió, su madre la esperaba tendiéndole los brazos en lo alto de la escalera; entonces ocurrió una escena cuyas difíciles explicaciones fueron omitidas en su novela autobiográfica. Con una violencia increíble, la acusó de haberlo matado. ¿A qué respondía esto? Lo único que descubrimos los lectores de la obra es que, después de muchos lustros de matrimonio, antes de acostarse cada uno se despedía del otro desde su cuarto con un cordial y quizás frío buenas noches. Habían pasado de los primeros ardores a la calma de la convivencia prolongada.

Como resultado la mandaron para continuar sus estudios espasmódicos, interrumpidos también por la Persecución Religiosa, interna nuevamente al Sagrado Corazón de Monterrey acompañada por Maggie. En el andén del ferrocarril, amenazó a su madre -que siempre decía "yo nunca he tenido la curiosidad de fumar, y le pido a Dios que a mis hijas jamás se les ocurra hacerlo" (Amor, 1951: 31) - con volverse fumadora empedernida, cosa que no cumplió. El rigor conventual se le figuraba una cárcel y contravino cuanta norma le impusieron. Hacía hasta lo indecible ganándose el repudió de sus maestras y la tirantez culminó al escribir una composición en que comparaba a las monjitas con payasos, elefantes, domadores y leones componentes de un circo estrafalario. Las rimas no causaron gracia y la expulsión se impuso (García, 1997: 51). Además se había distanciado de su hermana porque mientras una ganaba medallas de excelencia, Pita se había convertido en verdadero dolor de muelas. Regresó transformada físicamente y encontró cambios en su hogar. Sus hermanas mayores, desafiando las normas de la época, decidieron tomar distintos empleos ante el desplome económico. Remozaron los sótanos y con la asesoría de pintores entusiastas establecieron la Galería de Arte Mexicano, pionera en la ciudad, para montar exposiciones en un ambiente sofisticado al que acudían personas connotadas entre las que aparecía Guadalupe ensayando actitudes seductoras.

Poco después tomó una decisión que marcaría su suerte, cerca de los quince o diecisiete años según se saquen las cuentas, decidió fugarse con un hombre mayor, José Madrazo, dueño de una dehesa, La Punta, en Aguascalientes, que criaba toros bravos para las corridas en que formaban cartel Carlos Arruza, Armillita, Silverio Pérez y otras estrellas del momento. Una acción de tal naturaleza, que en un hombre no hubiera sido terrible, tomada por una joven de buen apellido la estigmatizó y causó serios comentarios y puso a su familia en el centro del huracán; sin embargo todos debieron también respirar aliviados. El silencio burgués arribaba a las habitaciones y con él la calma, cesaron pleitos y discusiones aunque la casa hipotecada hacía veinte años estaba a punto de venderse. Desde muy niña, Guadalupe había padecido tenaces insomnios que trastocaban el orden doméstico. Las tinieblas la asustaban creyéndose rodeada de peligros y sólo al despuntar las mañanas lograba dormir catorce o dieciséis horas llenas de inconsciente desconsuelo. Además, convertía en víctima de sus berrinches y desplantes a cuanto ser humano tuviera cerca. Desde siempre sus hermanos la consideraban extraña y en un pasaje de su novela, dijo: "Por algún motivo insignificante, mientras estábamos comiendo un día, Jorge (José María) y yo empezamos a pelear. Antes de que pudiera contenerme, le arrojé la cuchara que tenía en la mano rozándole la oreja. Iracundo me gritó: ¡Loca, estúpida, enana!” (Amor, 1951: 70). Con todo, luego de su fuga varios parientes dejaron de tratarla por lo menos al pronto. Lo resentía porque siempre estuvo orgullosa de pertenecer a un clan y hablaba constantemente del desdén que le mostraban con amigos y conocidos encontrados ocasionalmente como Hugo B. Margaín (García, 1997: 112). Los cambios se sucedieron. Carolina y Manuela se casaron. José María preparaba su boda con Mercedes Martínez Gallardo. A mediados de 1937 la madre se mudó a la calle de Génova y Guadalupe ocupaba sus días demostrando dotes de eficaz decoradora. Escogía para su departamento muebles Chippendale, cortinas rayadas y todo lo que cuadraba a sus caprichos.

Empezó a frecuentar restoranes y puntos de reunión como el Café París donde por las tardes se juntaban Jaime Torres Bodet, Andrés Henestrosa, Lola Álvarez Bravo, Carlos Chávez, Fernando Benítez, Octavio Barrera y otros más. Iba a la casa de Salvador Novo -que luego la satirizó en unos de sus Diálogos comparándola desventajosamente con Sor Juana- a quien había conocido antes y quien resultaba una especie de imán por ser él mismo muy hábil para captar reflectores, engalanar columnas de sociales y darse tiempo para escribir buenos poemas y crónicas memorables. En su cercanía conoció a Manuel González Montesinos, nieto de un presidente de la República durante algún paréntesis del porfirismo, que usaba anillo heráldico en el dedo meñique y con su mirada azul codiciaba a sus alumnas más bellas en clases de gramática superior impartidas con bastante desgana en la Facultad de Filosofía y Letras. Conoció también a Enrique González Martínez y a Enrique Asúnsulo. La impulsaban para mejorar. Le aconsejaron que leyera a Manuel José Othón y clásicos españoles como Fray Luis de León, y San Juan de la Cruz, Francisco de Quevedo y Federico García Lorca. Xavier Villaurrutia fue una influencia decisiva. Aprendió sus décimas y las repetía en cualquier circunstancia gracias a unas dotes de memoriosa que había demostrado desde los diez años. Quería estar en todos lados y aparecía en diferentes reuniones, acompañada o no por Madrazo con quien jamás casó y con quien nunca vivió bajo el mismo techo; pero 
que la mantenía lujosamente cumpliéndole sus caprichos. Se sentía culpable al haberla lanzado hacia la vida que ella tanto deseaba.

Luego de su complicado arreglo personal, alrededor del medio día abordaba un ruletero y se presentaba en lugares concurridos, el 1-2-3, el Ambassadeurs, Lady Baltimore, La Flor de México, o culminaba sus parrandas en Leda, El Waikiki, Eloínes, Las Veladoras, La Cucaracha y posteriormente El Quid y El Eco. Los que mantenían clientela exclusiva o atraían artistas. Por todos lados acrecentaba un anecdotario de impertinentes diabluras. Si alguien se le acercaba para conocerla, estiraba su mano de uñas rojas y se limitaba a confirmar: Todo lo que dicen de mí es cierto. Quería que hablara de ella bien o mal, pero que hablaran. A las reuniones de su casa acudían los componentes del Grupo Hiperión, acompañados de Henrique González Casanova. Iban, por supuesto, Jorge Portillo, su amante ocasional, y Ricardo Guerra. Y se presentaba en las celebraciones de conocidos suyos como Antonio Peláez incluso de improviso. En una carta a Edmundo O'Gorman, Sergio Fernández cuenta:

Y ¿quién llegó sin ser invitada? Pita Amor que, con un vaso de cristal a la mitad de agua, con una amapola en el centro, se presentó diciendo: Toñito, ¿verdad que me esperabas? Esta flor es para María. Y se metió a la fiesta sin ser convidada, con una faldita muy corta de organdí, su cara de muñeca y sus dientes de lobo.

La sala -digo- estaba tan a reventar que Pita quedó en el lado contrario de la Félix. Pero se las amañó de tal modo que cuando acordamos ya estaba junto a ella y en una y las otras le pidió prestadas las joyas y, cuando logró ponérselas se trepó en la pequeña mesa de la sala y gritó a voz en cuello: “Torero, torero..." por lo que usted, sin mayor premura, la llevó del brazo hasta la puerta y le dijo: "Pita, basta" y la echó de la casa. Toño entonces comentó en voz alta: Es bruja; no sé cómo se enteró de la fiesta. Guadalupe me va a matar de un coraje; que bueno que Edmundo la corrió debió de haberla echado a patadas. Pero luego volvió y empezó a decir sus versos, inconteniblemente, por lo que la Félix pasado un rato se levantó y se fue, ella sí, para siempre (Fernández, 1995: 12).

Le había dado a Edmundo O'Gorman una serie de poemas escritos con lápiz de cejas y en boletos de tranvías y papeles de estraza. Él la instó a pasarlos en limpio y la ayudó a corregirlos para publicarlos en su Editorial Alcancía que con Justino Fernández publicaba libros artesanales de tiraje reducido. Propuso el título, tomado de un verso, y el 16 de septiembre de 1946 salieron fuera de comercio los ciento cincuenta ejemplares de Yo soy mi casa, dedicado a C.S. de A., su madre muerta poco antes. Siguió Puerta obstinada, con el mismo sello editorial y un tiraje mayor de doscientos cincuenta ejemplares, el 14 de abril de 1947, y Círculo de angustia, Editorial Stylo (1948), doscientos ejemplares al cuidado de Antonio Caso, júnior. Los libros causaron asombro porque nadie los esperaba. Se dijo que se los había escrito Enrique Asúnsolo, poeta además de pintor, que Alfonso Reyes, admirador de las mujeres bonitas había intervenido no sólo con sus consejos sino en la redacción. ¿Qué otra cosa podía pensarse de una muchacha carente de educación formal, a duras penas terminó la primaria, una muchacha que se había puesto el mundo por montera haciendo su voluntad y dejando a cuantos la conocían con la boca abierta por uno u otro motivo?

Pita imitaba a los místicos y vivía como los paganos. No formaba parte de ningún círculo protector, trabajaba entre las cuatro paredes de su alma. Sin embargo quiso formar parte del Grupo de los Doce compuesto por intelectuales connotados porque se creía capaz de departir con hombres inteligentes como sor Juana lo hizo en el locutorio de San Jerónimo. Naturalmente no fue aceptada. Sin desmayar, se las arreglaba para que su rostro apareciera hasta en tarjetas postales y tuvo defensores resueltos. José Revueltas escribió un artículo de cuatro cuartillas, apasionado como toda su obra, en el cual la consideraba una iluminada capaz de mantener sobre su cabeza al Ángel de la Anunciación (Revueltas, 1948: 58). La comentaba Efrén Hernández. Y Margarita Michelena, que también publicaba en Stylo y gozaba prestigio gracias a su gran inteligencia manifiesta en Tiras de colores, (1943) y El laurel del ángel (1948), redactó un artículo:

$\mathrm{Al}$ abrir cualquiera de esos libros desgarrados y profundos, asalta la fascinación, la emocionada certeza de hallarse frente a un genuino poeta, es decir, frente a ese que, de acuerdo con Rilke, puede decir a Dios cómo son los hombres y a los hombres cómo es Dios. Porque fundamentalmente es poeta sólo aquel en quien la angustia, la belleza y el misterio se convierten en llaves para revelar un mensaje (Michelena, 1948).

Aparte encarecía un apego a las métricas clásicas que otros reprochaban. Alababa su desnudez de adjetivos y sus finales acertados. Ese ensayo fue leído el 17 de enero de 1951 presentando al primer recital que Guadalupe ofreció en Bellas Artes y se incluyó a manera de prólogo en la segunda edición de Poesías completas (1960). Círculo de angustia (1948) apareció con catorce sonetos y décimas conteniendo algunos de sus momentos más desgarrados: "Estos pies, que de tanto caminar, se han herido sin dar con el sendero". A los veintiocho años la fama de Guadalupe crecía. Celebró la salida de Polvo (1949) con una fiesta en que iluminaba su departamento con luces mortecinas. Ceñida en un atuendo gris, había colocado tules grises por doquier. No despreciaba ninguna circunstancia para ser comentada y obtenía resultados. Roberto Cabral del Hoyo unió su opinión a la de otros admiradores con varios artículos:

Por alejado que me encuentre de nuestro llamado mundo literario, no puedo menos que saber lo mucho que se dice y se escribe -tanto es ello- sobre Guadalupe Amor, y en caso de haber faltado la oportunidad para aquilatar el alto valor de su poesía en su poesía misma, ya el número y la índole de quienes la denigran me hubiera dado de él 
seguro indicio, más cierto y más seguro desde luego que el de aquellos, para quienes la poesía ha venido a ser algo así como un deslumbramiento (Cabral del Hoyo, 1949).

Y siguió elogiándola en varias formas, incluso al escribir un poema inspirado en Polvo. Más o menos por esas fechas Pita se unió a la caravana de poetas mujeres que fueron a Veracruz para conocer a Gabriela Mistral, hecho que Rosario Castellanos aprovechó en su obra de teatro, cuento, capítulo de novela, Tablero de damas. Comentan que Gabriela se portó bastante descortés con ella probablemente por al desprecio que demostraba hacia los indígenas y la afectación de sus modales. ¿Cómo saberlo a ciencia cierta? La literatura y la prensa recogieron el encuentro de otro modo, con cierto tono satírico o con la inocencia de quien vio a Pita como una prófuga del escándalo que la perseguía tercamente (Valdés, 1949). Poesías completas (1951) se publicaron en Aguilar, papel Biblia, cantos dorados y espléndida fotografía, por recomendación de José Gaos. Traía una cintilla con la firma de Alfonso Reyes, nada de comparaciones odiosas, aqui se trata de un caso mitológico, y le dieron a Guadalupe satisfacciones que ninguna de sus congéneres habían tenido y la oportunidad de viajar a España, ofrecer recitales en varias universidades, retratarse en la Alambra vestida de mora, favorita del harén, recorrer algunos países europeos y africanos como Italia y Marruecos y cocinar materia prima para que Carmen Conde escribiera sobre ella un ensayo comparándola con Juana de Asbaje y Calderón de la Barca, no sólo por la forma de sus liras y redondillas sino por su "denso pensar". Pita aseguraba que escribía con enorme facilidad siguiendo ritmo y rima como si fueran música, confesaba que le costaba más esfuerzo vivir que hacer poemas y condenaba a los escritores insinceros creyendo que cometían el peor de los errores. Reconocía que su conversación generalmente estaba reducida a problemas personales, lo mismo que sus poemas. Para ella contaba poco el mundo exterior. El soneto, la décima, la lira, el terceto, en lugar de limitar su expresión, se la desbrozaban para poderse concentrar en el contenido de sus intuiciones y abstracciones. Detestaba los nombres propios y se complacía aseverando que no usaba palabras con mayúsculas sino para nombrar a Dios, eje central de sus inspiraciones junto con la angustia y la muerte. Pero Antonio Castro Leal dijo sobre ella unas frases cuya lucidez antecede e porvenir: "No hay duda en que la sorda combustión en que vive su espíritu acabará por encenderse en las frenéticas llamas" (Castro Leal, 1953: 462).

En Poesía mexicana moderna 1950-1960, Max Aub sacó tres poemas suyos "Por qué me desprendí de la corriente", "Volar encadenada" y "Ven disfrazado", que contiene algunas de sus líneas más conocidas en las que se nota la influencia determinante de Santa Teresa: "A este fuego abrasador que en mi corazón llamea dale un motivo que sea como eterno combustible". Aub también redactó una nota bibliográfica que refleja la personalidad de Pita en ese momento y puede tener varias lecturas: “... Representa el éxito. Cierto afán natural de exhibir sus gracias y su facilidad le ha proporcionado público, no sólo lector: hizo teatro, aparece en la televisión, usa de la radio y de los discos para dar a conocer su poesía, la mejor vendida estos últimos años. Los moldes más tradicionales no se le resisten sin importarle mucho Dios o el diablo" (Aub, 1969). Enseguida anota los títulos que hasta ese momento le parecían representativos: Décimas a Dios (1953), "Hoy Dios vino a visitarme, y entró por todos mis poros; cesaron dudas y lloros, y fue fácil entregarme", Sirviéndole a Dios de hoguera (1958), dedicado a José Madrazo, Todos los siglos del mundo (1959) (Aub, 1969: 167-170). Carlos Monsiváis, que consideró a Margarita Michelena una poeta de enormes posibilidades, en Poesía mexicana del siglo XX, (1966) dijo que Pita Amor había convertido la retórica de su tiempo en espectáculo social, que, al menos por una temporada, le había devuelto al libro de poesía sus posibilidades de venta, y recogió tres composiciones de Polvo, "soy cómplice infeliz de algo más alto" (Monsiváis, 1966). Para entonces había salido también Poesía (1948) y Antología poética (1956) en Espasa Calpe. Pita viajó a Sudamérica para promoverlo. Monsiváis demostraba que las simpatías e inclinaciones iban cambiando y en un libro futuro, Poesía Mexicana II 1915- 1979 (Monsiváis, 1979), ni siquiera se ocupó de mencionarla, aunque siempre tuviera y aún tenga defensores. En el prólogo a Las amargas lágrimas de Beatriz Shéridan, Alberto Dallal dijo: "Pero todos sabemos que no es una figura que se bajó del cuadro que Diego Rivera le pintó desnuda; todos sabemos que ella va murmurando un ritmo, una armonía, el final de un soneto terrible que nadie, sólo Pita, puede escribir y gritar (Amor, 1981: 10)

En 1959, el Fondo de Cultura Económica sacó su único libro de cuentos, Galería de títeres compuesto por cuarenta textos de pocas páginas. En la camisa llevaba una viñeta en forma de murciélago chupador de su amigo Antonio Peláez que a pesar de cimas y simas en su amistad la había incluido en una carpeta de dibujos sobre mujeres célebres en México y continuó ilustrándole libros posteriores. El cuidado del estilo, el ahorro de palabras y el respeto por la página revelan su cercanía con Juan José Arreola a quien por entonces había tomado como maestro. Los personajes son generalmente femeninos, usó estructuras lineales. Le dio importancia a principios y remates atinados. Se preocupó poco por encontrar los tres pasos básicos ortodoxos y por darle tensión al clímax, cosa que acerca estos relatos a la estampa. De tan sintéticos, los títulos parecen barajas de la lotería que nuestro pueblo canta, "El lago", "El ajusticiado" "El camisón" "La hoja", "El pobre". Algunos están cerca del poema en prosa dejándole al lector la última palabra cuando se maneja la malicia necesaria para tal efecto. Por ejemplo "Los globos", "I...i", "El universo", dedicado a Mireya Cueto o "El candelabro" en que describe a Dolores Puche con verdadero entusiasmo, "embelesada ante la armonía de las estrellas y la verdura vibrante de las hojas, ante los niños desnutridos y los rollizos bebés enfundados en el barroquismo de sus estambres". Algunos como "La señora Yamez", “Mónica Mijares” o “Raquel Rivadeneira” ya los había prefigurado en su novela Yo soy mi casa, con igual título que su primer poemario, publicada dos años 
antes también por el Fondo de Cultura Económica. A mi juicio la novedad radica en la temática que nadie en México había tratado antes, "La cansada" toca la situación de la madre de familia que en silencio y buen humor soluciona problemas domésticos sin tener derecho a quejarse ni a encontrar satisfacciones, la yegua de fuerza que las feministas encarecieron después. "Margarita Montescos", antes asediada por múltiples admiradores, gasta su fortuna rogándole a un joven que se acueste con ella, "La sucia" no se baña porque necesita su propio olor para soportar su soledad nocturna y pensarse acompañada, "El pescado" sintetiza la tragedia del homosexual que le compone poemas a un militar quien en un final abierto acaba matándolo. "La pétalo" estuvo veinte años paralítica y su sangre se fue secando mientras su hija se marchitaba con agrio misticismo, encadenada a un lecho de enferma tratando de descifrar balbuceos. Habían establecido un pacto tácito de paralela consunción. "La solitaria" se queda en la cama sin fuerzas para levantarse por haberse masturbado durante horas enteras. Apoyada en la ventana observa los vidrios rotos de enfrente, una nube desalentada que cubre el sol, el pasto ralo cerca de una alcantarilla y vuelve a tocarse con sórdida tenacidad. "Televicentro" recoge el diálogo reiterativo de la mujer que limpia los baños condenada desde sus orígenes a un destino sin redenciones. Además se habla de joyas que dan a las señoras sensación de estabilidad; de la vejez ineludible, al descubrirla en otros se vuelve el espejo que nos refleja. La vejez aparece en estos personajes cerca de los cuarenta años cuando precisamente la propia Guadalupe empezaba a perder su lozanía, las desveladas, los recorridos nocturnos y los excesos comenzaban a marcarle ojeras y a darle una apariencia exhausta. "La cómplice" aborda la amistad femenina capaz de llegar a la eutanasia; pero "La del abrigo de cacomixtle" destaca por su rapidez y economía, por su fuerza desencarnada. Dos mendigos, madre e hijo, recorren por las noches el Paseo de la Reforma cobijándose en zaguanes, acariciándose sin recelo cerca de la iglesia Votiva, bastándose a sí mismos siempre juntos, siempre cometiendo incesto.

Los personajes de distinta condición guardan lazos invisibles. Toman lugar en un museo de seres solitarios deambulando sin rumbo como si Dios, desentendido de su quehacer, hubiera regado sobre la tierra puños de sal. Nunca se cuestionan ni detienen su marcha, actúan como ciegos que recorren a tientas su camino y aguardan su fin incluso sin quererlo. Padecen graves problemas existenciales a los que han sido sentenciados y nunca se detienen a pensar sumidos en su decadencia y egocentrismo. Demuestran, como diría Platón, que una vida sin reflexiones no vale la pena ser vivida. Quizá germinó esta serie cuando Pita compraba en una miscelánea títeres fabricados en Guanajuato vestidos de manta, con caritas de barro coloridas. Los escogía cuidadosamente, pasaba horas viéndolos antes de elegirlos, y ansiaba tener todos los que colgaban de un alambre que atravesaba el pequeño establecimiento.
En 1957 Guadalupe dio a conocer su novela Yo soy mi casa de 350 páginas. Como decía anteriormente, con el mismo título de su primer poemario; pero si en el otro caso aludía a cuestionamientos ontológicos, en éste literalmente alude al lugar que la marcó para siempre. En la portada mostraba el dibujo con un pañuelo en la cabeza que le hizo Diego Rivera y que tuvo mucho tiempo a la entrada de su departamento. Aprovechaba como epígrafe sus octosílabos, "Casa redonda tenía de redonda soledad: el aire que la invadía era redonda armonía de irresistible ansiedad." Y cerraba con otro: "Al decir casa pretendo expresar que casa suelo llamar al refugio que yo entiendo que el alma debe habitar". Era consciente de su celebridad y una autobiografía la ayudaba a incrementarla. Es verdad que la memoria tiende a inventar y a contar mentiras para darle rienda suelta a la imaginación. Una imaginación que nos explica a nosotros mismos, aunque nos transformemos al atrapar cuanto guardamos dentro sin separarlo de las emociones. ¿Hasta qué punto le ocurrió esto a Guadalupe en aras de embellecerse a sí misma trastocando su realidad? Al momento de contarnos sus historias, todos los escritores lo hacen. Guadalupe se apoyó en adjetivos que no utilizaba en su poesía, cambió el apellido Amor por Román, aumentándole una letra, y dejó su propio apelativo y las iniciales en algunos nombres y, ella que juzgaba la insinceridad como lo más condenable en un artista, omitió explicaciones que hubieran sido de importancia para entender mejor la psicología y actitudes de protagonistas que transitan los párrafos casi convertidos en sombras. En cambio develó su niñez tormentosa, insomne e insoportable, de géminis oscilante. Niña sensible, inquieta, preguntona, afrontaba su soledad en llamas. Ociosa empedernida, no dejaba de pensar. Maltrataba a su nana Pepa que a escondidas fumaba cigarros Gardenia Chorrito y la consentía hasta la exageración y exasperaba a las demás sirvientas que la asustaban con mariposas negras o con el robachicos, a pesar de lo cual les improvisaba sobre las mesas danzas frenéticas o cantaba a grito pelado tangos de moda que nadie quería oír. “Te quiero, me decía el embustero; te juro que mi amor es noble y puro; vidita, cuando acabe de estudiar..."; pero temía a la institutriz de amigas suyas por representar la autoridad. Padecía temperamento de hechizada y memoria que recordaba, con escenas de locura, humillantes acontecimientos pasados o los olvidaba después de dormir algunos momentos. Observaba la jaula de un canario pensando que necesitaba volar sobre los tejados vecinos y más allá hacia confines lejanos. Sufría lo indecible cuando descubría cómo desangraban guajolotes o sacrificaban cerdos destinados a placeres culinarios. Pensaba con terror que iban a estar colgados gran parte de la mañana y que al recorrer, desde los sótanos a la azotea, no iba a librarse de verlos. Habló de su apetencia desmedida, de su glotonería y gusto por los dulces que devoraba hasta el final de sus días. $Y$ ese rubro le proporcionó materia prima para un pasaje cargado de color parecido al bodegón "Puesto de mercado" pintado por Olga Costa. 
Yo devoraba con los ojos todo aquello que no podría devorar con la boca. Y antes de marcharme, pasaba revista a las vitrinas de la dulcería Larín. Aquí un estante lleno de mazapanes de almendra; junto a él, cien pomos con todas las figuras del mundo, hechas caramelo; después, el enorme burro de chocolate, y a sus pies, docenas de muñecas de azúcar. Más allá, cajas y cajas de galletas finísimas; botes de vidrio repletos de dátiles, pasas y cerezas, y un tumulto de paletas en forma de animales; y miles y miles de dulces envueltos como flores... (Amor, 1981: 98)

Sus ojos abarcaban la noche, el pecho y los brazos llenos de manchas rojas y calientes en una negrura sin hendiduras traicioneras. Sus oídos escuchaban los ruidos callejeros, las campanas de las iglesias cercanas, el silbato del camotero o del tren nocturno, las fugaces sirenas de las ambulancias y hasta las risas y rezos del día que se habían quedado estampados en los muros. Dedicaba el libro a sus amigos con una hermosa letra Palmer tendiente a inclinar los renglones, seña de temperamentos depresivos. Recurrió a una estructura novedosa reconstruyendo sus vivencias infantiles en una especie de recorrido imparable por la casa donde había nacido. Se permitió juegos temporales, puesto que más bien cada cuarto, iluminado de modo distinto y con diferentes aromas, la llevó a la aprehensión de un recuerdo o de anécdotas sobre la Decena trágica, la Lucha Cristera y otros pasajes históricos que había escuchado. Invocaba al Dios, que tanto oyó invocar, como muletilla que la ayudaba rítmicamente. Empezó describiendo una incompatibilidad imparable con su madre, el segundo personaje en importancia, pues como indica el título, la novela se narra en primera persona y atiende a un yo pertinaz. El primer apartado es la recámara, el baño azul moiré, los estucados del techo, la colcha tejida, el tocador ante el que cada mañana esta mujer metódica se trenzaba el pelo antes de emprender sus agobiantes tareas que sin embargo le permitían recibir y corresponder invitaciones. Comenzaban con una misa en la capilla cercana de la Divina Infantita, ataviada con minucioso lujo oriental, donde se había casado con un hombre mucho mayor de edad y desentendido de los imperativos diarios. Y seguía con cartas a su hermana, la Marquesa de Hermosillo del Rey, que frecuentaba casinos europeos, y no estaba cabalmente enterada de su situación; pero mandaba baúles pletóricos de regalos para cada componente de la familia.

Desde el principio se dejó sentado el imparable derrumbe de una fortuna que por años habían agotado en un nivel de vida que se empeñaban en sostener ayudados por la costurera Bibi y el Monte de Piedad. Allí quedaban los aretes de brillantes, los prendedores de perlas y turquesas, los anillos de amatistas que servían para amainar los rigores del gasto y detener lo inevitable. Les cortaron la luz ocho meses eternos, doscientos veintiséis días en que se alumbraban con medio kilo de velas compradas cada mañana. Los años dejaban su pátina y habían vuelto algunos rincones parajes siniestros y ninguno tan húmedo y decepcionante como la habitación de los porteros, salvo los sótanos convertidos en lagunas donde se había ahogado un gato. Los tapices se desgastaban, las baldosas se desprendían y las macetas, aunque tuvieran las iniciales de la abuela paterna, se veían devastadas, la escalera de servicio era deplorable con su hierro carcomido y roto en varios peldaños. El espacio que servía de cava con libreros viejos estaba lleno de telarañas:

Un día mamá ordenó a una criada que bajase al sótano para quitar los tumultos de polvo que cubrían las botellas. La sirvienta cumplió escrupulosamente su tarea, al punto que con estropajo y jabón las limpió una a una, dejándolas relucientes y sin su etiqueta original. Nunca más se pudo distinguir el espeso vino de Borgoña del animoso Chablis (Amor, 1981: 81)

Ese hurgar en el pasado hizo de Pita una maestra que con pocas líneas trazaba retratos y modas de la época y de la burguesía nacional con sus juicios y prejuicios: “Era Úrsula Vélez elegante a la inglesa, de pelo cano, huesosa; tenía la cara acribillada de arrugas, entre las que imperaba una boca torcida. Siempre vestía traje sastre y usaba un sombrerito masculino, suavizado por un velo" (Amor, 1981: 26). "Longoria era un chico de familia conocida, pero no muy encumbrada. Tocaba bien la guitarra y era cordial con todo el mundo. Oviedo parecía tener veinte años más de su edad; jamás miraba de frente y a mamá la inquietaba" (Amor, 1981: 68). "Algunas veces llegaba Gastón Rojas a la reunión de mi hermano. Más que él, llamaba la atención su traje y su arreglo esmeradísimo Educado en Francia era flexible y sonriente con mis hermanas mayores. A veces se dejaba arrebatar, sin darse cuenta, por el brío de una canción mexicana" (Amor, 1981: 68-69). “La Gorda Preciado, como le llamaba mamá, era cariñosa conmigo y jamás se molestó porque cantase con mi voz estridente o porque contara todas las mentiras que necesitaba para despejar mi selvática imaginación.” (Amor, 1981: 95) “! Las Salcedo, con vestidos de piqué blanco! ¡Las Salcedo, con zapatos de ante blanco, con calcetines y guantes blancos! (Amor, 1981: 93) “Algunas veces vi salir de su cuarto a Ignacia, nuestra gorda cocinera indígena, con labios henchidos de resentimiento. Iba envuelta en su rebozo palomo y en las manos llevaba un portamonedas" (Amor, 1981: 71). Y se esmera evocando a las personas más queridas: “...en aquel instante se reflejaba en el espejo veneciano su aristocrático perfil aguileño (de su padre), sus blancas patillas a la usanza del siglo XIX, su cuerpo endeble lleno de espíritu y de fatigas, su traje oscuro, y esa elegancia que no habían podido abatir ni los años, ni los sinsabores, ni las privaciones. Un halo de pureza parecía rodearlo y sus pasos eran tan mesurados que se diría que no tocaban el suelo" (Amor, 1981: 77).

Solamente un personaje se destacaba entre aquel refinado y convencional barullo; solamente las formas de mi madre sobresalían entre toda aquella engalanada concurrencia. Diríase que todos estaba como esfumadamente dibujados y que sólo mi madre estaba como esculpida en su propia belleza. Brillaba más que todas las luces del 
hall, de la sala, del comedor y del saloncito, que habiendo abierto sus puertas de par en par, formaban una sola unidad festiva Mi madre relucía en su traje negro de lentejuelas, y una cauda de pequeñísimas flores violeta, también luminosas, le caían sobre uno de sus marfilinos hombros. Una chalina de gasa lila daba inusitado resplandor a su rostro intocable (Amor, 1981: 114).

Pero esta admiración no contenía los malos entendidos, los pleitos ni la falta de afinidad entre ellas. En Mis crímenes (1986) Pita se acusa de haber matado a su madre por los incontables disgustos que le había causado. A lo largo de la novela se habla de ellos sin ahondar las causas. Se anota que alguna vez la madre dijo: le pido a Dios que te mueras por lo mala que eres. ¿Cómo explicar que una mujer piadosa anhele la muerte de su hija? Se intenta aclararlo hablando del aturdimiento que le acarreaba su legión de sirvientes, sus otros hijos, su beatífico marido, su estira y afloja con el dinero escaso, por todo lo cual no le alcanzaba ya el tiempo para atender las demandas de una niña llorona sentada arriba de una cómoda, retorcida en enojos epilépticos o escondida en el cesto de la ropa sucia sin que nadie se ocupara de buscarla. ¿Y con todo, las pequeñas garras ávidas no merecían ser comprendidas? ¿No merecía ser comprendida una criatura que anhelaba cuanto no podían darle y embargada de felicidad bajaba galopando el barandal de la escalera con el sonido del gong que anunciaba la comida que siempre la sedujo? María Elvira Bermúdez - atenta a reseñar las novedades bibliográficas- en una crítica muy acuciosa (Bermúdez, 1957: 3) confesó que estas omisiones sobre el porqué de una conducta le parecían graves faltas estructurales. La novela no entró entonces a lo psicológico ni reveló cabalmente los motivos de un comportamiento tan errático Quizás los genes nos caracterizan desde el vientre materno y cada quien trae consigo sus inclinaciones, sus iras y sus talentos. A lo mejor es así. La autobiografía en efecto no profundiza en esos aspectos, únicamente deja algunas pinceladas para entrever la desdicha e insatisfacción de una infanta mimada que adoró a su muñeca Conchis de celuloide rescatada de un basurero, la vestía con esmero como si fuera su alter ego y cuando un perro la trituró bajo sus colmillos, la enterró sin mayores alardes. Pita alargó ese pasaje como queriéndonos decir algo concerniente a su niñez, algo que no llegó a decirnos. En cambio su novela autobiográfica se tornó un documento valioso para rescatar las costumbres, los atuendos de una época y una clase social, con una mirada femenina, mordaz, irónica y despiadada a ratos. El trabajo narrativo hace que las palabras revoloteen como colibríes y la sonrisa nos seduzca.

Plasma las relaciones entre los de arriba y los de abajo. Mientras unos, a pesar de sus apuros, vivían todavía rodeados de porcelanas valiosas, vírgenes estucadas y tapetes franceses, los otros habitaban rincones desmantelados. No recibían el sueldo merecido y los patrones ni siquiera sabían su nombre, como en el caso de los porteros; sin embargo, por las tardes se juntaban a rezar el rosario en un supremo acto de solidaridad cristiana. Y los misterios y jaculatorias se repetían en monótono e imparable sonsonete mántrico, Arca de la alianza, Torre de marfil, Estrella de David, Puerta del cielo. Los asistentes arrodillados con hilos de cuentas en las manos se creían parte de un mismo núcleo casero y todos quedaban contentos por darle alientos a su fe, menos Pita que no borraba sus pensamientos lóbregos. Sabía que cada Ave María la acercaba a la temida noche en cuyas oscuridades parece emboscarse la muerte asesina del tiempo y evitaba la galería donde colgaban los retratos de su abuelo, escritor de cartas amenas, y su bisabuelo que la perseguían con miradas implacables.

La novela reconstruye los fusilamientos contra los muros de la cárcel de Belén a los que concurría la gente de la ciudad como si fueran espectáculo gratuito y que en nuestra literatura dieron tema a pasajes extraordinarios; fiestas infantiles animadas por loterías de juguetes; las posadas en que se adorna el portal con los peregrinos, se encienden velitas de colores y el burro y el toro toman su lugar ancestral durante nueve días seguidos. La Navidad con su árbol pletórico de esferas y la cena en que sacaban a relucir una de las siete vajillas que aún poseían, las copas de cristal firmes sobre la mesa como soldados antes de emprender batalla, las servilletas y manteles almidonados, los manjares exquisitos que no se comían a diario, el Nacimiento donde, en uno de sus actos imprevistos, Pita cambió al Niño por su muñeca Conchis. Las obras de caridad en la Colonia Romita. Acudían las señoras para darle pucheros y servirles a los pobres en supremos actos de humildad, imitando a Cristo en la Ultima Cena, o mostraban una esplendidez entre comillas, "se engalanaban como si fuesen a una gran recepción social, y realmente era estridente el contraste cuando doña Susana Cuervo de Infante, con su cara de avestruz, acentuada por las plumas del sombrero, entregaba, sonriendo forzada, un paquetito de ropa a una mujer rodeada de cuatro o cinco hijos famélicos" (Amor, 1981: 189). La novela habla también de las tardes de tejidos destinados a los huérfanos en que las hermanas Román, junto con sus amigas, creían pagar los beneficios de su vida con labores que presumían entre sí antes de gratificarse con cafés olorosos a climas tropicales y suculentas galletas:

Un grupo de muchachas de la mejor sociedad y alguna que otra de menos abolengo que lograba colarse, tejían para los niños pobres. Cada semana se preparaban colchas, chambritas y gorros de estambre. Luego los obsequiaban en una espléndida canasta orlada de listones a alguna mujer desamparada y próxima a ser madre. Después de coser y platicar sin tregua, la anfitriona ofrecía una merienda a sus compañeras de caridad (Amor, 1981: 256)

El mejor pasaje trabajado a base de luces y sombras, el mejor no sólo por ser extenso y detallado, todos son de muy diversos tamaños, reconstruye la Primera Comunión. La colcha china primorosamente bordada en antiguo raso azul eléctrico se había rescatado del Monte de Piedad para dar un fondo fastuoso al altar improvisado en 
el hall, cubierto de azahares, azucenas y cirios fervorosos. Oficiaba el Obispo de Morelos y Pita recibía la hostia en un reclinatorio, con el cabello cortado de polquita y fleco, vestido de organdí lleno de alforzas (aunque ella hubiera querido que estuviera recamado de perlas), limosnero, enaguas de encajitos, velo, misal de nácar, guantes de cabritilla y una enorme vela que llegaba al piso. El sol inundaba el recinto con un vértigo entusiasta; pero ella estaba atenta al desayuno colmado de pasteles, tamales, chocolate y golosinas, listo para servirse, y además no dejaba de pensar en los regalos, un caja con etiqueta de La Esmeralda, una moneda de oro o una insignificancia, y no dejaba embargar su corazón por un arrobamiento digno de lo que entonces se consideraba el día más importante de una vida, la ola de piedad iba y venía en compás marino a pesar del retiro al que había asistido como preparación. La misa se alargaba más de la cuenta, a ratos creía que iba a desmayarse y a ratos se fijaba en los invitados que con sus galas ocultaban alguna pared despintada o un zoclo carcomido y se enorgullecía de ser el centro de acontecimiento tan suntuoso. Por fin el copón llegó hasta ella y el pan eucarístico estuvo sobre su lengua, sus ansias eran un desbordante río de lava inundándola, sin que esto le impidiera a los ocho años atender la tos de un invitado o la inquietud de los sobrinos de otro que no podían estarse en paz imaginando la futura comilona igual que los demás niños presentes. Las cosas salieron como se habían previsto, hasta cuando se acabó la celebración y Pita advirtió que su moneda de oro había desaparecido. Entró a sus consabidas pataletas y en uno de sus gestos imprevistos jaló la colcha china y derrumbó el altar.

En la fuente se veía a sí misma reflejada como estrella; pero era la barda lo más atractivo. Se aferraba a sus barrotes enmohecidos por donde entraba un aire liberado. La barda le sirvió a su padre para escapar y esconderse durante la Persecución Religiosa. Y desde la barda, ella escuchaba los ecos de las conversaciones de las criadas o de su familia y se sentía desamparada en una soledad nacida de sí misma y cultivada a lo largo de su sobresaltada niñez. Rondaba la barda recapacitando en el tiempo, esa hemorragia lenta que nos lleva a la muerte. Jamás fue un refugio alegre sino una evidencia de que allí terminaba la casa.

Luego recordó a una vieja pintarrajeada que habían destajado misteriosamente junto con su manada de gatos en la calle de Abraham González. Recordó otros crímenes y decidió cometer uno más. Bajar la escalera como quien sube los peldaños de un cadalso, trajo a la mente las imágenes de sus abuelos, de sus tíos; pero agarró el picaporte con determinación incubada en años de soledad, clamores e incomprensión. Miró la fachada y se fue caminando acompañada por el viento.

Durante lustros motivaron chismes y comentarios sus relaciones con Dolores Puche, una española casada, empeñada en hacer una biografía de Isabel la Católica todavía inédita; pero en 1959, Pita se enamoró de Luis Antonio Camargo, alumno de
Juan José Arreola. Tuvo un hijo, Manuel. No se sintió capaz de cuidarlo y lo entregó a su hermana Carito para la que lo creciera junto con Carlos, su niño adoptado, en una quinta de San Jerónimo, hasta que en 1961, un mediodía de julio, sonó el campanazo trágico. La tía se distrajo contestando el teléfono. La cocinera se distrajo abriéndole la puerta al carnicero y el bebé de año siete meses, andariego como su madre, salió a la huerta y se acercó a un aljibe cubierto de lirios; pero se ahogó en un pozo. Sobrevinieron las clínicas psiquiátricas en México y en Cuernavaca. Sobrevino el derrumbe. Madrazo, cansado de sostenerla, había viajado a España. Los hermanos, dicen, no quisieron cubrir las rentas atrasadas y quitaron el departamento de Duero que jóvenes como Alberto Dallal rondaban sólo para verlo desde afuera. Mimí procuró tapar el sol con un dedo y, sin respetar opiniones de quien ya no podía defenderse, rompió cartas y documentos que certificaran la vida libre de su hermana. Sobrevino también la miseria ¿dónde quedaron los retratos que hubieran bastado para cubrir sus deudas y sostenerla? Hay varias hipótesis al respecto. Quizás se encuentren en colecciones particulares o en bodegas de museos. Pita comenzó su deprimida estancia en hoteles, Mayab, María Cristina, Del Bosque. Disfrazada de pordiosera se convirtió en el fantasma de la Zona Rosa - Nahui Ollín fue el fantasma del Correo- y atacaba con furibundos bastonazos a los desprevenidos transeúntes que pasaban cerca; pero aceptaba homenajes como el que le hizo Miguel Sabido en Bellas Artes, a los que se presentaba como una extraña reina de carnaval en silla de ruedas, la presentación en Casa Lamm de su biografía escrita por Michael Kart Schuessler o la exposiciones de retratos suyos donde exhibieron el esperpéntico e importante pintado por Olga Donde y uno de Marta Chapa a quien agradeció el gesto con varios sonetos y una carta. A partir de 1960, Max Aub, director de la emisora, le facilitó su último trabajo en Radio Universidad, el programa Variaciones sobre un motivo poético. Quince años llegó en taxi que la esperaba a la entrada y pagaban los empleados, sobre todo Rodolfo Chávez Parra quien el hablaba todas las noches a cambio de una décima. Así salieron las ciento setenta que formaron El zoológico de Pita Amor (1975). Intentó dar uno de sus aletazos publicitarios con una hojita "Paralelo entre la Virgen de Guadalupe y Guadalupe Amor" creyéndolo algo herético. Casi nadie se enteró de esa publicación. Y siguió improvisando malos sonetos a cambio de algunos pesos, convertida en vendedora ambulante de su obra. A lo mejor por su terror a la muerte, se sobrevivió a sí misma hasta mayo del 2000. Como Moisés al que tanto había compadecido, vio desde lejos el Monte Olimpo de nuestros clásicos. De tan apabullante, su leyenda acabó devorando su obra.

\section{REFERENCIAS BIBLIOGRÁFICAS}

Yo soy mi casa, Alcancía, México, 1946. 
Puerta obstinada, Alcancía, México, 1947.

Círculo de angustia, México, Stylo, 1947.

Polvo, Stylo, México, 1949

Más allá de lo oscuro, Stylo, México, 1951.

Poesías completas, Aguilar, Madrid, 1951. Segunda ED. 1961, prólogo de Margarita Michelena.

Décimas a Dios, Fondo de Cultura Económica, Col. Tezontle, 1953; segunda y tercera ED.

ibídem, 1954; cuarta ED. aumentada, Fournier, 1975.

Otro libro de amor, Fondo de Cultura Económica, Col Tezontle, 1955.

Antología poética, Austral, núm. 1956, Buenos Aires, 1956.

Yo soy mi casa, Fondo de Cultura Económica, México, 1957

Sirviéndole a Dios de hoguera, Fondo de Cultura Económica, Col. Tezontle, México, 1958.

Galería de títeres, Fondo de Cultura Económica, México, 1959.

Como reina de barajas, Fournier, México, 1966; segunda ED. 1975.

Fuga de negras, Fournier, 1966; segunda ED. 1975.

El zoológico de Pita Amor, Editorial V Siglos, México, 1975.

Las amargas lágrimas de Beatriz Shéridan, Katún, México, 1981.

A mí me ha dado en escribir sonetos, Katún, 1981.

48 veces Pita, Posada, México, 1983.

Paralelo entre la Virgen de Guadalupe y Guadalupe Amor, Hoja volante poética, México, 1983.

Soy dueña del universo, edición de la autora, México, 1984.

La jungla, Galería de Arte Misrachi, 1984.

Pita, por Guadalupe Amor, Imposible, México, 1985.

Mis crímenes, Federación Editorial Mexicana, México, 1986

Cuadros de una exposición, (dedicado a Dolores Puche), edición de la autora, México, 1986.

Cien sonetos a vuelo alto, Luzbel, México, 1987.

Los pájaros, edición de la autora, México, 1988.

La sombra del mulato, edición de la autora, 1989.

Liras, edición de la autora, 1990.

\section{HEMEROGRAFÍA SELECTA}

"Dos sonetos de Pita Amor", América, 54, 30 de agosto de 1947, pp. 22-23.

"Dos nuevas décimas", América, 56, junio de 1948, pp. 42-43

"Aunque parezca imposible...", América, 57, septiembre de 1948, pp. 47-48.

“Décimas al polvo", América, 59, febrero de 1949, pp. 57-60.
“Tres décimas", Fuensanta, 3, febrero de 1949, p. 1.

"Selecciones de polvo", América, 65, abril de1951, p.9.

"Más Allá de los oscuro", Revista Mexicana de Cultura, 51, 30 de marzo de 1952.

"Viejas raíces empolvadas", "Por qué me desprendí...", “Volar encadenada”, "En el fondo",

"Ven disfrazado", en Antonio Castro Leal, La poesía mexicana moderna, Fondo de Cultura Económica, México, 1953, pp. 461-464.

"Tan sólo una mirada", Anuario de la poesía mexicana 1955, pp. 9-10.

“Décimas", Anuario de la poesía mexicana 1957, p. 13.

“Décimas a la luna”, La Cultura en México, 391, 13 de agosto de 1959, p. VIII.

"Por qué me desprendí", “Volar encadenada”, "Ven disfrazado", en Max Aub: Poesía mexicana 1950-1960, Aguilar, México, 1960, pp. 167-170.

“Décimas al polvo”, “Son mis viejas raíces empolvadas” en Carlos Monsiváis, La poesía mexicana del siglo XX, Empresas Editoriales, S.A. México 1966, pp. 664-665.

"El chícharo", Revista de la Universidad de México, 8 de abril de 1980, pp. 10-11.

"Dos sonetos", Diálogos, jul-agosto de 1980, pp. 10-11.

“Décimas a Dios", Diorama de la Cultura, 12 de abril de 1981, pp. 12-13.

"Poemas de Pita Amor", Sábado 183, 9 de mayo de 1981, p. 8.

"Poemas", Siempre!, 1486, 16 de diciembre de 1981, pp. 52-53.

“Tan sólo una mirada" en Enrique Jaramillo Levi: Poesía erótica mexicana 1889-1980, Editorial Domés S.A, México, 1982. pp. 357-359.

“Tres décimas a Rafael Coronel”, El Faro, 6 de febrero de 1984, p. 3.

\section{Cuentos Antologados}

"La cómplice", Anuario del cuento mexicano, Instituto Nacional de Bellas Artes, México, 1960 pp. 11-12.

"Margarita Montescos", en Mujeres en la Literatura, p. 42.

“La señora Yamez", “El té de la ternura”, "La que sube la escalera”, “La cansada”, “Raquel Rivadeneira", Aurora Ocampo: Cuentistas mexicanas siglo XX, Universidad Nacional Autónoma de México, México, 1976. pp. 83-94.

"La cómplice", Beatriz Espejo y Ethel Krauze, Mujeres engañadas, Alfaguara, México, 2004. pp. $49-52$.

\section{Biografías}

García, E., Redonda soledad. La vida de Pita Amor, Grijalva, México, 1997, 406 p. Schuessler, M. K., La undécima musa, Guadalupe Amor, Diana, México, 1995. 


\section{ENTREVISTAS ESCOGIDAS}

Asher, D., “Como retraté a Pita Amor”, Sábado, 386, 9 de marzo, 1985, p. 6.

Camargo, A., "La crisis sólo existe para los que no tienen espíritu. G.A.", Diorama de la Cultura, 2 de febrero de 1985, p. 4.

del Río, M., “Entrevista con Pita Amor”, Diorama de la Cultura, 23 de agosto de 1959, p. 3.

García, E., “Hoy soy más joven que antes”, Proceso, 55, 21 de noviembre de 1977, pp. 54-55.

Hahn, D., “López Velarde, Neruda, Villaurrutia y García Lorca, los poetas más importantes del español: G. A.", Unomásuno23 de junio de 1984, p. 15.

Landeros, C., "Pita Amor y la leyenda”, El Día, 26 de marzo de 1964, p. 9

Millar, B. y González, A., "No creo en mi vida ni en mi muerte” La SBA, 129 de noviembre de 1977, pp. 2-5.

Poniatowska, E., “Guadalupe Amor”, México en la Cultura, 288, 1954, p.2.

Rosales, J. N., "Sombra y presencia de Sor Juana. Pita responde", Siembre!, 510, 3 de abril de 1963, pp. 41, 70 . 